Prethodno priopćenje Primljen: 4. svibnja 2021.

Antonia Ćurić, mag. prim. educ.

Prihvaćen: 15. rujna 2021.

Rijeka

curic.antonia@gmail.com

https://orcid.org/0000-0001-6570-7726

\title{
SAMOPROCJENA SOCIJALNIH KOMPETENCIJA STUDENATA UČITELJSKOG STUDIJA IZ KONTEKSTA ODRŽIVOG RAZVOJA
}

Sažetak: Socijalna kompetentnost važan je ishod odgoja i obrazovanja za održivi razvoj jer se procesima socijalnog učenja pridonosi stvarnim promjenama. Održivi razvoj označava razvojne procese koji kombiniraju ekonomsku i socijalnu dobrobit i učinkovitost s ekološkom otpornošću i zdravljem, kako ovdje i sada, tako i drugdje, i u budućnosti.

Cilj istraživanja bio je ispitati studentsku samoprocjenu socijalne kompetentnosti. U istraživanju je sudjelovalo 127 studenata Učiteljskog fakulteta u Rijeci. Konstruirana je i validirana Skala samoprocjene socijalnih kompetencija u kontekstu održivog razvoja. Analizom skale utvrđena su tri faktora - Usmjerenost na cilj, Samoizražavanje i Globalne kompetencije. Rezultati istraživanja ukazuju na zadovoljavajuću primjenjivost konstruiranih skala, ali kako je riječ o preliminarnom istraživanju, ove zaključke iznosimo s oprezom. Utvrđena je umjerena do visoka samoprocjena studentskih socijalnih kompetencija. Iako rezultati nisu zabrinjavajući, ukazuju na potrebu obogaćivanja interpersonalnih vještina budućih učitelja kako bi njihova sigurnost $u$ vlastitu izvedbu bila veća.

Ključne riječi: održivi razvoj, socijalne kompetencije, stavovi, studenti, učitelji.

\section{UVOD}

Održivi razvoj je koncept utemeljen izvještajem Naša zajednička budućnost (engl. Our Common Future), izdanom od strane Svjetske komisije za okoliš i razvoj (engl. World commission on environment and development, WCED) $u$ listopadu 1987. godine, a obuhvaća razvoj koji zadovoljava potrebe sadašnjosti bez ugrožavanja budućih generacija da zadovolje vlastite potrebe (WCED, 1987), odnosno takav način organizacije društva koji omogućuje njegovo dugoročno postojanje (Mubtaker, 2020). Iako je definicija WCED-a najčešće upotrebljavana, postoji niz kritičara koji smatraju da je previše općenita te da ne 
nudi suglasje u razumijevanju pojma, čime postaje politička floskula oko koje se svi mogu složiti (Mebratu, 1998, Ročnević i sur, 2008). Ipak, dva su ključna koncepta ove definicije - koncept potreba kojima treba dati prioritet i ideja ograničenja okoliša da zadovolji sadašnje i buduće potrebe (Mebratu, 1998).

Konkretizaciju implementacije održivog razvoja donosi UN 1992. godine na konferenciji u Rio de Janeiru izdajući Agendu 21, cjeloviti program koji propisuje djelovanje na lokalnoj, nacionalnoj i globalnoj razini u svrhu održive budućnosti. Agenda 21 u poglavlju 36. određuje odgoj i obrazovanje kao ključan faktor promicanja održivog razvoja i poboljšanja sposobnosti ljudi za rješavanje pitanja zaštite okoliša i razvoja (UN, 1993). Iako obrazovanje ne može samo doprinijeti održivoj budućnosti, bez njega je ona neostvariva.

Odgoj i obrazovanje za održivi razvoj jedan je od najvećih izazova s kojim se čovječanstvo suočava jer zahtjeva pripremu sadašnjih generacija za budućnost koja slijedi, bez da znamo kakva će ta budućnost zaista biti. Autor Robert Prescott-Allen je (2011) napredak prema održivosti usporedio s odlaskom u zemlju u kojoj ranije nismo bili - ne znamo kakvo je to mjesto ni kako se do njega dolazi (Laininen, 2018). Odgoj i obrazovanje za održivi razvoj treba pripremiti pojedinca za razumijevanje i progresivno održivo djelovanje u složenom i nesigurnom okolišu te sudjelovanje $u$ društveno-političkim procesima kojima bi djelovao u smjeru održivih promjena, poput očuvanja okoliša i prirodnih resursa ili socijalne i ekonomske jednakosti (UNESCO 2015; 2017).

Tri su globalne inicijative predstavile važan korak u provedbi Agende 21, a to su Milenijski ciljevi razvoja (engl. Millennium Development Goals, 2000 - 2015), Obrazovanje za sve (engl. Education For All, 2000 - 2015.) i Desetljeće pismenosti (engl. United Nations Literacy Decade, 2003. - 2012.), kojima je dodatan doprinos dala rezolucija Desetljeće odgoja i obrazovanja Ujedinjenih naroda za održivi razvoj (engl. Decade of Education for Sustainable Development, 2005. - 2014). Ona je za cilj imala integraciju principa, vrijednosti i prakse održivog razvoja u sve aspekte odgoja i obrazovanja, s ciljem rješavanja socijalnih, gospodarskih, kulturnih i ekoloških problema. Po završetku programa Desetljeća, njegov nastavak slijedi u okviru Programa globalnog razvoja do 2030. godine (Agenda 2030) koji predstavlja nadgradnju osam milenijskih razvojnih ciljeva koji su obilježili razdoblje do 2015. Program je usvojen od strane država članica Ujedinjenih naroda 25. rujna 2015. godine u New Yorku, a sadrži sedamnaest ciljeva održivog razvoja koji se mogu ostvariti samo uz snažno globalno partnerstvo i suradnju te obrazovanje koje omogućuje socijalno-ekonomski rast (UN, 2015). Održivost je interes konkretnog socijalnog aktera - pojedinca, grupa i institucija (Lay i Puđak, 2008), radi čega je za njeno ostvarenje presudna socijalna kompetentnost svih uključenih aktera. 


\section{KOMPETENCIJE U KONTEKSTU ODGOJA I OBRAZOVANJA ZA ODRŽIVI RAZVOJ}

Organizacija za ekonomsku suradnju i razvoj (engl. Organisation for Economic Cooperation and Development, OECD) je 2018. predstavila metriku za usporedbu 'globalne kompetencije' petnaestogodišnjaka, koja je ugrađena u Program međunarodnog ocjenjivanja učenika (engl. Programme for International Student Assessment, PISA) kao odgovor na ciljeve održivog razvoja. Pritom, globalne kompetencije osim znanja, kognitivnih vrijednosti i vještina uključuju socijalne vještine i stavove.

Odgovornost za ostvarivanje punih potencijala učenika je u stručnosti učitelja koja se ogleda u posjedovanju i praktičnoj primjeni općih i specifičnih znanja, vještina i stavova, odnosno posjedovanju općih i specifičnih kompetencija. Uloga učitelja je presudna u razvoju učeničkih vještina i kapaciteta za rad koji je neophodan za poboljšanje društvene dobrobiti i razvoj zajednice, odnosno za pripremanje učenika na sudjelovanje u društvenim odnosima i budućem svijetu. Dosadašnja istraživanja ukazuju da studenti učiteljskih i nastavničkih studija te odgojno obrazovni djelatnici prepoznaju važnost održivog razvoja i stručnih usavršavanja u tom području (Anđić i Ćurić, 2020; Anđić i Tatalović Vorkapić, 2017; Anđić, 2015; Borić i sur., 2008; Vukelić i sur., 2018), ali i da istovremeno slabije procjenjuju etičke vrijednosti, emocionalno upravljanje $\mathrm{i}$ održivost (Anđić, 2017; Cvitković, 2018). Takve rezultate potvrđuju i rezultati istraživanja koji ukazuju da ne postoji sustavan pristup obrazovanju za održivi razvoj, već se on provodi tek kroz inicijative pojedinaca (Kostović-Vranješ, 2016; Raditya-Ležaić i sur., 2018; Rončević i sur., 2008).

Učitelji više od polovice radnog dana provode u interakciji s drugim ljudima, što čini socijalne kompetencije temeljnim kompetencijama odgovornima za njihov profesionalni uspjeh (Kanning i sur., 2012). Socijalno kompetentno ponašanje dovodi do interesa svih strana, a karakterizira ga činjenica da osoba istodobno postiže vlastite ciljeve i poštuje interese drugih ljudi. U odgojno obrazovnim ustanovama na socijalne kompetencije utječe okruženje za učenje $\mathrm{u}$ kojem se ističe sposobnost međusobne komunikacije i suradnje (Gedviliené, 2012). Autori Leganés-Lavall i Pérez-Aldeguer (2016) objašnjavaju da komunikacija i suradnja uključuju vještine timskog rada, rješavanja problema, donošenja odluka, suočavanja s izazovima, uspostavljanja i održavanja odnosa, samokontrole, asertivnosti, odgovornosti, poštovanja, kreativnosti i kritičkog mišljenja (Leganés-Lavall i Pérez-Aldeguer, 2016). Razvoj navedenih vještina je značajan za omogućavanje osobnog rasta, samopoštovanja i poštivanja socijalno utemeljenih ljudskih normi.

Prema preporukama Europskoga parlamenta i Vijeća Europe o Ključnim kompetencijama za cjeloživotno učenje (2006) pojedinci bi tijekom školovanja trebali ovladati sljedećim kompetencijama: komuniciranje na materinskom 
jeziku, komuniciranje na stranom jeziku, matematička, znanstvena i tehnološka kompetencija, digitalna kompetencija, učiti kako učiti, socijalne i građanske kompetencije, osjećaj za inicijativu i poduzetništvo te kulturna svijest i izražavanje. Pritom se socijalna i građanska kompetencija odnosi na sposobnost učinkovitog sudjelovanja u vlastitom društvenom i radnom životu te uključivanje u aktivno i demokratsko sudjelovanje. Takvo objašnjenje socijalnih kompetencija obuhvaća dvije perspektive - perspektivu obrazovanja za odraslu osobu i perspektivu obrazovanja za građanstvo. Perspektiva obrazovanja za odraslu osobu socijalne kompetencije promatra kao razvojni konstrukt te ih kao takve smatra ishodom normalnog razvojnog puta djeteta (Zwaans i sur., 2006). Ova se perspektiva odnosi se na društveno naučeno ponašanje, na znanja, vještine i stavove koje je pojedinac stekao u određenom društvenom kontekstu i u njemu ga primjenjuje. Pritom je naglasak stavljen na interpersonalne i intrapersonalne komponente. U perspektivi za građanstvo naglasak je na sposobnosti osobe da kao građanin sudjeluje u demokratskom i multikulturalnom društvenom kontekstu, što obuhvaća kritičko promišljanje o društvenoj ravnoteži, jednakosti i tumačenju kulturnih razlika (Zwaans i sur., 2006).

Pojam „građana održivosti“, koji se spominje u UNESCO-vu dokumentu „Obrazovanje za održivi razvoj: ciljevi učenja“, opisuje socijalno kompetentnog pojedinca koji odgovorno i aktivno sudjeluju u društvenom životu (UNESCO, 2017). Pritom se, održivi razvoj ne može ograničiti samo na jednu perspektivu socijalnih kompetencija te ih on sagledava u cjelini. Iako svaka perspektiva stavlja fokus na različite elemente socijalnih kompetencija, uviđamo da tek njihovim sagledavanjem $u$ cijelosti možemo obuhvatiti društvenu dimenziju održivog razvoja. Stoga, autori Knippenberg i sur. (2005) naglašavaju potrebu razrade podataka za procjenu društvenih aspekata održivog razvoja i održive interakcije između društvenih, ekonomskih i ekoloških područja.

Kako u domaćoj, tako i u stranoj literaturi najčešće pronalazimo ispitivanje socijalnih kompetencija djece (Buljubašić Kuzmanović i Livazović, 2010; Dodge i sur., 1986; Livazović, 2012; Martinsone 2016), dok se malo pozornosti obraća na čimbenike koji određuju socijalnu kompetentnost odgojno obrazovnih djelatnika. Značajan doprinos istraživanju socijalnih kompetencija odraslih dali su autori Annemieke Zwaans i sur. $(2006 ; 2016)$ te Uwe Peter Kanning i Christoph Herrmann $(2012 ; 2015)$ koji su proveli detaljne analize socijalnih kompetencija i time u većoj mjeri obuhvatili perspektivu obrazovanja za odraslu osobu i perspektivu obrazovanja za građanstvo.

Analiza FIBEL upitnika (njem. Feedback Inventar zur berufsbezogenen Erstorientierung für Lehramtsstudierende, hr. Povratne informacije o popisu za početno osposobljavanje studenata učiteljskog usmjerenja) rezultirala je sa 17 primarnih društvenih kompetencija, koje su sažete u četiri sekundarna faktora: društvena orijentacija, dinamično i proaktivno ponašanje, samokontrola i refleksna egzistencija, a koje su prepoznate od posebnog značaja za uspjeh u 
učiteljskoj profesiji. Riječ je o dijagnostičkom alatu za samoprocjenu namijenjenom budućim učiteljima (Kanning i Herrmann, 2012), čijim smo se podatcima također služili pri konstrukciji našeg mjernog instrumenta.

Ovim se istraživanjem željela ispitati percepcija studenata, budućih učitelja, o vlastitim socijalnim kompetencijama u kontekstu održivog razvoja te validirati konstruiranu skalu socijalnih kompetencija. Kako je riječ o preliminarnom istraživanju, očekuje se da će rezultati istraživanja uputiti na daljnje unaprjeđivanje instrumenta za mjerenje socijalnih kompetencija u kontekstu održivog razvoja.

Zadatci istraživanja bili su sljedeći:

1. Prilagoditi i potvrditi izgrađenu ljestvicu socijalnih kompetencija.

2. Utvrditi procjenu studenata o vlastitim socijalnim kompetencijama.

3. Utvrditi stavove studenata o vlastitim socijalnim kompetencijama spram godine studija.

4. Utvrditi procjenu studenata o vlastitim socijalnim kompetencijama spram broja stranih jezika koje govore.

5. Utvrditi stavove studenata o vlastitim socijalnim kompetencijama spram veličine mjesta iz kojeg dolaze.

Sukladno postavljenim zadatcima istraživanja postavljene su sljedeće hipoteze:

H1 Sastavljen upitnik je objektivan, valjan i pouzdan instrument za mjerenje socijalnih kompetencija u kontekstu održivog razvoja.

H2 Studenti visoko procjenjuju socijalne kompetencije u kontekstu održivog razvoja.

H3 Ne postoji statistički značajna povezanost godine studija i procjene socijalnih kompetencija u kontekstu održivog razvoja.

H4 Ne postoji statistički značajna povezanost broja stranih jezika koje studenti govore i procjene socijalnih kompetencija u kontekstu održivog razvoja.

H5 Ne postoji statistički značajna povezanost veličine mjesta prebivališta studenta i procjene socijalnih kompetencija u kontekstu održivog razvoja.

\section{METODOLOGIJA}

Istraživanje je provedeno pomoću online upitnika u listopadu 2020. godine na uzorku od 127 studenta Učiteljskog studija, Učiteljskog fakulteta Sveučilišta u Rijeci, Hrvatska. Provedeno je u skladu s etičkim načelima te je ispunjavanje upitnika bilo anonimno i dobrovoljno. U navedenom razdoblju u Republici Hrvatskoj se provode specijalne epidemiološke mjere suzbijanja epidemije bolesti COVID-19, zbog čega je bilo teško doći do ukupnog broja studenata.

Studenti prve godine čine najveći dio uzorka, $N=40$. Ispitano je $N=20$ studenata druge godine, $\mathrm{N}=3$ studenta treće godine, $\mathrm{N}=35$ studenata 4 . godine $\mathrm{i}$ $\mathrm{N}=28$ studenata 5. godine. Svi studenti su naveli da se služe engleskim jezikom i veći broj studenta je ženskog spola, $\mathrm{N}=121$, radi čega poznavanje engleskog jezika i spol nisu uključeni kao varijable. 
Za potrebe ovog istraživanja konstruiran je poseban anketni upitnik. Upitnik se sastojao od uvodnog dijela koji je uz sociodemografske podatke sadržavao pitanje o poznavanju stranih jezika te skalu procjene socijalnih kompetencija iz konteksta održivog razvoja. Skala procjene socijalnih kompetencija iz konteksta održivog razvoja konstruiran je s ciljem procjene socijalnih kompetencija studenata, budućih učitelja, a sadržavala je 29 čestica na kojima su sudionici procjenjivali svoje stavove na Likertovoj skali od 5 stupnjeva, gdje je 1 označavalo potpuno ne slaganje, a 5 potpuno slaganje.

Za konstrukciju upitnika korištene su čestice FIBEL upitnika (Kanning i Herrmann, 2012). Autori Kanning i Herrmann su se, kako bi došli do varijabli koje mjere socijalnih kompetencija učiteljske profesije, poslužili istraživačkim pristupom, jer ne postoji čvrsta teorija socijalnih kompetencija. Proveli su istraživanje kroz četiri koraka - prvo je proveden intervju s učiteljima kako bi se generirale situacije ključne za uspjeh u svakodnevnom radnom životu. Kompetencije su grupirane u 10 dimenzija koje se mjere pomoću FIBEL-a: organizacijske vještine, složenost percepcije, sposobnost rada pod pritiskom, motivacija za inovacije, samoizražavanje, samopouzdanje, asertivnost, spremnost na suradnju, prosocijalnost, spremnost za obrazovanje. U drugom koraku provedena su dva empirijska istraživanja kako bi se smanjio broj dimenzija, a u trećem i četvrtom koraku su provedena istraživanja kako bi se provjerila valjanost upitnika te provela njegova standardizacija. Zaključno je provedena eksplorativna faktorska analiza, rotacija varimax, i na deset dimenzija dobivena su 3 faktora - 1. Mirna i poštena interakcija unutar razreda, 2. Ponašanje u školskom kontekstu i 3. Pozitivan utjecaj na kontrolu socijalnih procesa u školi. Pri konstrukciji našeg upitnika korištene su one varijable koje su pokazale najviša zasićenja na svakoj dimenziji FIBEL-ovog upitnika i nadopunjene su varijablama koje opisuju dimenzije prosocijalnog ponašanja, spremnosti za podučavanje, spremnosti za suradnju, percipiranja odnosa, motiviranosti za motivaciju, sposobnosti rada pod pritiskom, samopouzdanje, organizacijske vještine, samoizražavanje i asertivnost. Ukupno je preuzeto i prilagođeno 17 varijabli FIBEL-ova upitnika te im je dodijeljena oznaka SK.

Kako kulturna raznolikost i interkulturno obrazovanje doprinose socijalnim aspektima održivosti (Bogović i Čegar, 2012) osim navedenih varijabli, upitnik je obuhvatio 12 varijabli koje se odnose na interkulturno obrazovanje i stavove o društvenim i okolišnim rizicima, a koje su preuzete i prilagođene iz PISA-inog upitnika o globalnim kompetencijama (2018). Varijable su označene oznakom OR, a formulirane su kako bi bile usmjerene na stavove i vrijednosti iz pozicije učitelja: OR24 Imam povjerenja u svoju sposobnost da djelujem $i$ utječem na rezultate aktivnosti pri postizanju cilja (rad do dolaska do cilja), OR8 Odluke donosim na demokratski način, uključujući dobnu ravnopravnost i razmatrajući različite perspektive, OR31 Sposoban sam sagledati okolišne, ekonomske i društvene probleme u cjelini i razumjeti njihove posljedice, OR32 
Mogu predvidjeti dugoročni utjecaj ljudskih akcija u budućnosti, OR19 Nastale sukobe rješavam nenasilno (pregovaranje, pronalazak kompromisa,...), OR28 Učenicima predstavljam različite interkulturalne perspektive kako bih poticao inkluziju unutar razreda, OR10 Rado sudjelujem u različitim društvenim i građanskim akcijama, OR29 Mogu razumjeti različite interkulturalne perspektive mojih učenika, OR9 Rado raspravljam ideje s kolegama iz različitih područja, OR17 Sposoban sam za razumijevanje društvenih zbivanja na nacionalnoj i međunarodnoj razini, OR13 Spreman sam prihvaćati prijedloge od drugih, SK16 Sposoban sam nastupati kao otvorena, spontana, duhovita i domišljata osoba pred grupom ljudi bez da zanemarim svoje mišljenje o temi i OR30 Smatram da bi svijet bolje funkcionirao kad bi postojalo manje različitih kultura.

Prije provedbe obrade podataka rekodirane su varijable „SK21 Osjećam da sam pod stresom kad znam da imam nekoliko stvari za obaviti tijekom dana" $\mathrm{i}$ „OR30 Smatram da bi svijet bolje funkcionirao kad bi postojalo manje različitih kultura" od 1-5 prema 5-1, gdje je 5 označavao najveće neslaganje a 1 najveće slaganje. Dobiveni podatci obrađeni su statističkim programom SPSS Statistica.

\section{REZULTATI I RASPRAVA}

Kako bi se utvrdile mjerene karakteristike korištenog instrumenta, pristupilo se ispitivanju mjera unutarnje koegzistencije skale socijalnih kompetencija i njezinih 29 čestica kroz Principal Components Analysis (PCA). Prije provedbe PCA procijenjena je prikladnost podataka za faktorsku analizu. Izračunata je vrijednost Cronbach alfa koeficijenta koja iznosi $\alpha=0.836$, odnosno standardizirani Cronbach alfa $\alpha=0,847$. Pregledom korelacijske matrice otkriveno je mnogo koeficijenata s vrijednostima jednakima ili višima od 0,3 . U nastavku istraživanja provedeno je testiranje pretpostavki primjerenosti podataka za faktorsku analizu pomoću Kaiser-Meyer-Olkin mjere (KMO) i Barlettova testa sferičnosti. Rezultati Kaiser-Meyer-Olkin mjere prikladnosti uzorka je zadovoljavajuća $(\mathrm{KMO}=, 692)$, a Barlettov test sferičnosti potvrđuje adekvatnost podataka za faktorsku analizu $(\chi 2=134,182, \mathrm{df}=406, \mathrm{p}<, 000)$. Također, pojedinačne KMO mjere za svaku zasebnu česticu veće su od vrijednosti koeficijenta 0,3. Dobiveni rezultati ukazuju na faktorabilnost korelacijske matrice.

Analiza glavnih faktora otkrila je prisutnost devet faktora s karakterističnim vrijednostima preko 1 , koje objašnjavaju $20,8 \%, 8,9 \%, 6,96 \%, 6,3 \%, 5,8$ $\%, 5,3 \%, 4,6 \%, 4,2 \%$ i 3,7 \% varijance. Rezultati paralelne analize potvrdili su 5 faktora, čije vrijednosti premašuju vrijednosti praga dobivene pomoću jednako velike matrice slučajnih brojeva (29 čestica x 127 ispitanika). Pregledom Screen Plot utvrđeno postojanje točke loma iza petog faktora. Na osnovi Cattell kriterija odlučeno je da se za dalje istraživanje zadrži petofaktorsko rješenje koje objašnjava 49,8 \% varijance. 
Za utvrđivanje latentne strukture Skale socijalnih kompetencija provedena je faktorska analiza uz kosokutnu rotaciju faktorskih osi (oblimin rotacija) i ekstrakciju faktora metodom najveće sličnosti (maximum likelihood) čije je rješenje uputilo na manji broj faktora zbog malog broja čestica i niskih saturacija. Uslijedile su postepene analize kojima su izbačene čestice koje su remetile faktorsku strukturu i sadržajnu valjanost faktora. Izbačene su čestice: „SK11 Uvijek saslušam ljude koji mi dođu ispričati svoje probleme“, „OR13 Spreman sam prihvaćati prijedloge od drugih“ i „OR19 Nastale sukobe rješavam nenasilno".

Provedeno je testiranje pretpostavki primjerenosti podataka za faktorsku analizu pomoću Kaiser-Meyer-Olkin mjere (KMO) i Barlettova testa sferičnosti. Rezultati Kaiser-Meyer-Olkin mjere prikladnosti uzorka je zadovoljavajuća $(\mathrm{KMO}=, 712)$, a Barlettov test sferičnosti potvrđuje adekvatnost podataka za faktorsku analizu $(\chi 2=1169,273, \mathrm{df}=325, \mathrm{p}<, 000)$.

Najjasnija i najčišća struktura dobivena je na 26 čestica i tri izlučena faktora. Objašnjena varijanca na tri faktora iznosila je 31,2 \%: 5,731 objasnilo je $22 \%$, 2,409 objasnilo je 9,3 \% i 1,886 objasnilo je 7,3\% varijance.

Između prvog i drugog faktora postojala je slaba korelacija $(\mathrm{r} 12=0,159)$, a između trećeg i druga dva faktora korelacija je bila srednja negativna $(\mathrm{r} 13=-$ $0,351, \mathrm{r} 23=0,-318$ ). Visina korelacija uputila je na opravdanost korištenja kosokutne rotacije faktorskih osi (oblimin rotacija) jer faktori nisu nezavisni.

Konačna faktorska struktura prikazana je u Tablici 1 .

Tablica 1. Prikaz rezultata faktorske analize

\begin{tabular}{lccc}
\hline \multicolumn{1}{c}{ Čestica } & \multicolumn{3}{c}{ Faktorska zasićenja } \\
\cline { 2 - 4 } & $\mathbf{1}$ & $\mathbf{2}$ & $\mathbf{3}$ \\
\hline SK20 Mnogi ljudi kažu da sam organizirana osoba &, 787 &, 054 &,- 100 \\
$\begin{array}{l}\text { SK25 Sposoban sam pouzdano strukturirati i organizirati } \\
\text { Svakodnevni život; uključujući aktivnosti, zadatke, sastanke }\end{array}$ & $\mathbf{, 6 9 8}$ &, 015 &,- 020 \\
$\begin{array}{l}\text { i sl. } \\
\begin{array}{l}\text { OR24 Imam povjerenja u svoju sposobnost da djelujem i } \\
\text { utječem na rezultate aktivnosti pri postizanju cilja }\end{array}\end{array}$ & $\mathbf{, 6 3 2}$ &,- 012 &,- 183 \\
$\begin{array}{l}\text { SK23 Sposoban sam raditi koncentrirano i bez prekida, } \\
\text { noseći se s različitim zadatcima bez da osjećam pritisak }\end{array}$ & $\mathbf{, 6 0 1}$ &,- 034 &,- 015 \\
$\begin{array}{l}\text { SK22 Kad god odlučim postići nešto, uspijem ostvariti svoj } \\
\text { cilj }\end{array}$ & $\mathbf{, 5 5 0}$ &, 090 &,- 245 \\
$\begin{array}{l}\text { SK21_rec Ne osjećam da sam pod stresom kad znam da } \\
\text { imam nekoliko stvari za obaviti tijekom dana }\end{array}$ &, 444 &,- 024 &, 126 \\
$\begin{array}{l}\text { OR10 Rado sudjelujem u različitim društvenim i } \\
\text { građanskim akcijama }\end{array}$ &, 113 & $\mathbf{, 6 8 2}$ &,- 036
\end{tabular}


Tablica 1. (nastavak) Prikaz rezultata faktorske analize

\begin{tabular}{|c|c|c|c|}
\hline \multirow{2}{*}{ Čestica } & \multicolumn{3}{|c|}{ Faktorska zasićenja } \\
\hline & 1 & 2 & 3 \\
\hline SK7 Uživam radeći u timu &, 011 & ,665 &, 276 \\
\hline SK14 Volim biti u centru pozornosti &,- 189 &, 522 &,- 134 \\
\hline SK26 Volim isprobavati nove stvari &,- 110 & ,422 & ,079 \\
\hline $\begin{array}{l}\text { OR9 Rado raspravljam ideje s kolegama iz različitih } \\
\text { područja }\end{array}$ &, 120 & ,370 &,- 135 \\
\hline $\begin{array}{l}\text { SK15 Tijekom diskusije suprotnu stranu mogu uvjeriti u } \\
\text { vlastito mišljenje }\end{array}$ &,- 047 & ,362 &,- 107 \\
\hline $\begin{array}{l}\text { OR17 Sposoban sam za razumijevanje društvenih zbivanja } \\
\text { na nacionalnoj i međunarodnoj razini }\end{array}$ & , 109 & ,334 &,- 004 \\
\hline $\begin{array}{l}\text { SK16 Sposoban sam nastupati kao otvorena, spontana, } \\
\text { duhovita i domišljata osoba pred grupom ljudi bez da } \\
\text { zanemarim svoje mišljenje o temi }\end{array}$ &, 164 & ,321 &,- 187 \\
\hline $\begin{array}{l}\text { SK27 Motiviran sam iskušati prilike i mogućnosti da } \\
\text { djelujem i prilagodim stvari kako bi ih poboljšao }\end{array}$ &, 179 & ,311 &,- 174 \\
\hline $\begin{array}{l}\text { OR31 Sposoban sam sagledati okolišne, ekonomske i } \\
\text { društvene probleme u cjelini i razumjeti njihove posljedice }\end{array}$ &, 167 & ,278 &,- 213 \\
\hline $\begin{array}{l}\text { SK12 Sposoban sam promatrati i prepoznavati međuljudske } \\
\text { odnose, unutarnje procese i strukture odnosa, te koristiti te } \\
\text { informacije da bih predvidio ponašanje i izbjegao konflikte }\end{array}$ &,- 153 &, 131 &,- 640 \\
\hline $\begin{array}{l}\text { OR32 Mogu predvidjeti dugoročni utjecaj ljudskih akcija u } \\
\text { budućnosti. }\end{array}$ &, 085 &,- 045 &,- 631 \\
\hline $\begin{array}{l}\text { SK33 Mogu podučavati učenike o latentnim (skrivenim) } \\
\text { zahtjevima društva s ciljem postizanja individualnog } \\
\text { osjećaja odgovornosti }\end{array}$ & ,119 &, 005 &,- 625 \\
\hline $\begin{array}{l}\text { OR28 Učenicima predstavljam različite interkulturalne } \\
\text { perspektive kako bih poticao inkluziju unutar razreda }\end{array}$ &, 038 &,- 010 &,- 521 \\
\hline $\begin{array}{l}\text { SK6 Dobro predviđam kako će se drugi ponašati u } \\
\text { određenim situacijama. }\end{array}$ &,- 006 &,- 046 &,- 486 \\
\hline $\begin{array}{l}\text { OR29 Mogu razumjeti različite interkulturalne perspektive } \\
\text { mojih učenika }\end{array}$ &,- 104 &, 029 &,- 409 \\
\hline $\begin{array}{l}\text { SK18 Sposoban sam stajati iza svog mišljenja i interesa u } \\
\text { situaciji neslaganja i opozicije bez kršenja društvenih normi } \\
\text { ponašanja }\end{array}$ &, 172 &,- 003 &,- 400 \\
\hline
\end{tabular}


Antonia Ćurić: Samoprocjena socijalnih kompetencija studenata ...

Tablica 1. (nastavak) Prikaz rezultata faktorske analize

\begin{tabular}{lrrr}
\hline \multicolumn{1}{c}{ Čestica } & \multicolumn{3}{c}{ Faktorska zasićenja } \\
\cline { 2 - 4 } & $\mathbf{1}$ & $\mathbf{2}$ & $\mathbf{3}$ \\
\hline $\begin{array}{l}\text { OR8 Odluke donosim na demokratski način, uključujući } \\
\text { dobnu ravnopravnost i razmatrajući različite perspektive }\end{array}$ &, 202 &, 141 & $\mathbf{- , 3 4 6}$ \\
$\begin{array}{l}\text { SK34 Učitelj bi trebao obraćati pažnju na oblikovanje } \\
\text { socijalnih vještina učenika }\end{array}$ &, 223 &, 014 & $\mathbf{- , 2 3 8}$ \\
\hline
\end{tabular}

Najveće zasićenje na prvom faktoru imale su varijable „SK20 Mnogi ljudi kažu da sam organizirana osoba“ $(=, 787)$ i ,SK25 Sposoban sam pouzdano strukturirati $i$ organizirati svakodnevni život; uključujući aktivnosti, zadatke, sastanke $i$ sl.“" (=,698), što znači da ga one sadržajno najtješnje opisuju. Osrednje zasićenje na prvom faktoru imale su varijable OR24 $(=, 698), S K 23$ $(=, 632), S K 22$ (,601), SK21 (,550). Nisko zasićenje imala je varijabla $S K 21$ rec $(=, 444)$ i varijabla OR30_rec $(=, 298)$, koja je svrstana pod prvi faktor. Varijable koje su ušle u prvi faktor dominantno opisuju organizacijske vještine, sposobnost rada pod pritiskom i samoučinkovitost pa je prvi faktor imenovan faktorom „Usmjerenost na cilj“. Provjerom unutrašnje suglasnosti varijabli u prvom faktoru izračunat je Cronbach alfa koeficijent koji iznosi $\alpha=, 401$; standardizirani $\alpha=, 513$.

Na drugom su faktoru faktorska zasićenja bila osrednja i niska. Najveće zasićenje imale su varijable „OR10 Rado sudjelujem u različitim društvenim $i$ građanskim akcijama“ (=,682) i „SK7 Uživam radeći u timu“ (=,665). Varijable koje su ušle u drugi faktor opisuju volju za sudjelovanjem, ekstrovertiranost, inovativnost i asertivnost pa je drugi faktor nazvan „Samoizražavanje“. Unutrašnja suglasnost varijabli u drugom faktoru, Cronbach alfa koeficijent, iznosi $\alpha=, 727$; standardizirani $\alpha=, 725$.

$\mathrm{Na}$ trećem faktoru zasićenja su bila osrednja i niska. Najveće zasićenje na trećem faktoru imaju varijable „SK12 Sposoban sam promatrati i prepoznavati međuljudske odnose, unutarnje procese i strukture odnosa, te koristiti te informacije da bih predvidio ponašanje i izbjegao konflikte“ (=-,640), „OR32 Mogu predvidjeti dugoročni utjecaj ljudskih akcija u budućnosti“ (=-,631), „SK33 Mogu podučavati učenike o latentnim (skrivenim) zahtjevima društva s ciljem postizanja individualnog osjećaja odgovornosti“ $(=-, 625)$ i „OR28 Učenicima predstavljam različite interkulturalne perspektive kako bih poticao inkluziju unutar razreda" (=-,521), dok nisko zasićenje imaju varijable SK6 $(-, 486)$, OR29 (-,409), SK18 (-,400), OR8 (-,346) i varijabla SK34 (-,238). Varijable koje su ušle u treći faktor primarno opisuju predviđanje ponašanja djelovanja, interkulturalne perspektive i djelovanje u zajednici pa je treći faktor imenovan „Globalne kompetencije“. Cronbach alfa koeficijent faktora Globalne kompetencije iznosi $\alpha=, 763$; standardizirani $\alpha=, 763$. 
U Tablici 2. prikazane su aritmetičke sredine i standardne devijacije na tri dobivene dimenzije socijalnih kompetencija te koeficijenti pouzdanosti Cronbah alpha za svaku subskalu i njihove međusobne korelacije. Iz vrijednosti koeficijenata Cronbah alphe uočavamo da su sve subskale pokazale zadovoljavajuće razine pouzdanosti. Također, utvrđene su pozitivne korelacije kod procijenjenih dimenzija cilj i samoizražavanje, a negativne korelacije kod dimenzije globalnih kompetencija.

Tablica 2. Deskriptivni pokazatelji: aritmetičke sredine (M), standardne devijacije (SD) odgovora, koeficijenti pouzdanosti Cronbach alpha i korelacije za sve subskale

\begin{tabular}{cccccccc}
\hline \multirow{2}{*}{ subskale } & \multicolumn{2}{c}{$\begin{array}{c}\text { prosječna } \\
\text { procjena }\end{array}$} & \multirow{2}{*}{$\begin{array}{c}\text { Cronbach } \\
\text { alpha }\end{array}$} & $\mathbf{M}$ & SD & & \multicolumn{3}{c}{ korelacije između subskala } \\
\cline { 6 - 8 } \cline { 5 - 7 } & & $\begin{array}{c}\text { Usmjerenost } \\
\text { na cilj }\end{array}$ & Samoizražavanje & $\begin{array}{c}\text { Globalne } \\
\text { kompetencije }\end{array}$ \\
\hline Usmjerenost na cilj & 3,86 &, 473 &, 513 & 1 &, 159 &,- 351 \\
\hline Samoizražavanje & 3,74 &, 466 &, 725 &, 159 & 1 &,- 318 \\
\hline $\begin{array}{c}\text { Globalne } \\
\text { kompetencije }\end{array}$ & 3,96 &, 373 &, 763 &,- 351 &,- 318 & 1 \\
\hline
\end{tabular}

Dobivena tri faktora upućuju na postojanje tri odvojene dimenzije socijalnih kompetencija iz kuta održivog razvoja koje osim što obuhvaćaju globalne kompetencije, obuhvaćaju faktore samoizražavanja i usmjerenosti na cilj koji su prepoznati kao druge dvije dimenzije socijalnih kompetencija. Rezultati su na svim trima dimenzijama visoki, čime možemo zaključiti da studenti procjenjuju da su u velikoj mjeri socijalno kompetentni. Ovi rezultati su značajni, jer je nastava proces interpersonalne komunikacije između njegovih sastavnih subjekata, a kvaliteta socijalnih kompetencija predstavlja značajan čimbenik u realizaciji nastavnog procesa.

Drugim istraživačkim zadatkom utvrdili su se stavovi studenata o socijalnim kompetencijama u području održivog razvoja. Tablica 3 pokazuje aritmetičke sredine (AS), standardne devijacije (SD), rang (minimum, maximum) te mjere asimetrije i kurtoze. 
Tablica 3. Deskriptivna statistika

\begin{tabular}{|c|c|c|c|c|c|c|c|c|}
\hline \multirow{2}{*}{ Čestica } & \multirow{2}{*}{ AS } & \multirow{2}{*}{ SD } & \multicolumn{2}{|c|}{ RANG } & \multicolumn{2}{|c|}{ ASIMETRIJA } & \multicolumn{2}{|c|}{ KURTOZA } \\
\hline & & & $\min$ & $\max$ & vrijednost & SD & vrijednost & SD \\
\hline $\begin{array}{l}\text { SK34 Učitelj bi } \\
\text { trebao obraćati } \\
\text { pažnju na } \\
\text { oblikovanje } \\
\text { socijalnih vještina } \\
\text { učenika }\end{array}$ & 4,91 &, 31 & 3 & 5 & $-3,76$ &, 21 & 14,84 & ,43 \\
\hline $\begin{array}{l}\text { SK11 Uvijek } \\
\text { saslušam ljude koji } \\
\text { mi dođu ispričati } \\
\text { svoje probleme }\end{array}$ & 4,80 & ,49 & 3 & 5 & $-2,42$ &, 21 & 5,15 & ,43 \\
\hline $\begin{array}{l}\text { OR19 Nastale } \\
\text { sukobe rješavam } \\
\text { nenasilno }\end{array}$ & 4,77 & ,60 & 2 & 5 & $-3,11$ & ,22 & 10,42 & ,43 \\
\hline \multirow{2}{*}{ Čestica } & \multirow{2}{*}{ AS } & \multirow{2}{*}{ SD } & \multicolumn{2}{|c|}{ RANG } & \multicolumn{2}{|c|}{ ASIMETRIJA } & \multicolumn{2}{|c|}{ KURTOZA } \\
\hline & & & $\min$ & $\max$ & vrijednost & SD & vrijednost & SD \\
\hline $\begin{array}{l}\text { OR13 Spreman } \\
\text { sam prihvaćati } \\
\text { prijedloge od drugih }\end{array}$ & 4,57 & ,62 & 3 & 5 & $-1,15$ &, 21 & ,26 & ,43 \\
\hline $\begin{array}{l}\text { OR29 Mogu } \\
\text { razumjeti različite } \\
\text { interkulturalne } \\
\text { perspektive mojih } \\
\text { učenika }\end{array}$ & 4,57 &, 70 & 2 & 5 & $-1,60$ &, 21 & 2,13 & ,43 \\
\hline $\begin{array}{l}\text { OR8 Odluke } \\
\text { donosim na } \\
\text { demokratski način, } \\
\text { uključujući dobnu } \\
\text { ravnopravnost } \\
\text { i razmatrajući } \\
\text { različite perspektive }\end{array}$ & 4,54 & ,60 & 3 & 5 &,- 95 &, 21 &,- 08 & ,43 \\
\hline $\begin{array}{l}\text { OR28 Učenicima } \\
\text { predstavljam } \\
\text { različite } \\
\text { interkulturalne } \\
\text { perspektive } \\
\text { kako bih poticao } \\
\text { inkluziju unutar } \\
\text { razreda }\end{array}$ & 4,48 & ,79 & 2 & 5 & $-1,28$ &, 21 &, 53 & ,43 \\
\hline
\end{tabular}


Tablica 3. (nastavak) Deskriptivna statistika

\begin{tabular}{|c|c|c|c|c|c|c|c|c|}
\hline \multirow{2}{*}{ Čestica } & \multirow{2}{*}{ AS } & \multirow{2}{*}{ SD } & \multicolumn{2}{|c|}{ RANG } & \multicolumn{2}{|c|}{ ASIMETRIJA } & \multicolumn{2}{|c|}{ KURTOZA } \\
\hline & & & $\min$ & $\max$ & vrijednost & SD & vrijednost & SD \\
\hline $\begin{array}{l}\text { SK18 Sposoban } \\
\text { sam stajati iza } \\
\text { svog mišljenja i } \\
\text { interesa u situaciji } \\
\text { neslaganja i } \\
\text { opozicije bez } \\
\text { kršenja društvenih } \\
\text { normi ponašanja }\end{array}$ & 4,47 & ,60 & 3 & 5 &,- 67 & ,21 &,- 49 & ,43 \\
\hline $\begin{array}{l}\text { SK27 Motiviran } \\
\text { sam iskušati prilike } \\
\text { i mogućnosti } \\
\text { da djelujem i } \\
\text { prilagodim stvari } \\
\text { kako bi ih poboljšao }\end{array}$ & 4,29 & ,68 & 3 & 5 &,- 44 &, 21 &,- 80 & ,43 \\
\hline $\begin{array}{l}\text { SK26 Volim } \\
\text { isprobavati nove } \\
\text { stvari }\end{array}$ & 4,26 & ,77 & 2 & 5 &,- 80 &, 21 &, 15 & ,43 \\
\hline
\end{tabular}

SK12 Sposoban

sam promatrati

i prepoznavati

međuljudske

odnose, unutarnje

procese i strukture

odnosa, te koristiti

$\begin{array}{llllllll}4,24 & , 66 & 3 & 5 & -, 32 & , 21 & -, 75 & , 43\end{array}$

te informacije

da bih predvidio

ponašanje $i$ izbjegao

konflikte

OR9 Rado

raspravljam ideje

$\mathrm{s}$ kolegama iz

$\begin{array}{llllllll}4,20 & , 76 & 2 & 5 & -, 79 & , 21 & , 53\end{array}$

različitih područja

OR31 Sposoban sam sagledati

okolišne,

ekonomske i

$\begin{array}{llllllll}4,10 & , 75 & 2 & 5 & -, 40 & , 21 & -, 47 & , 43\end{array}$

društvene probleme

u cjelini i razumjeti

njihove posljedice 
Tablica 3. (nastavak) Deskriptivna statistika

\begin{tabular}{|c|c|c|c|c|c|c|c|c|}
\hline \multirow{2}{*}{ Čestica } & \multirow{2}{*}{ AS } & \multirow{2}{*}{ SD } & \multicolumn{2}{|c|}{ RANG } & \multicolumn{2}{|c|}{ ASIMETRIJA } & \multicolumn{2}{|c|}{ KURTOZA } \\
\hline & & & $\min$ & $\max$ & vrijednost & SD & vrijednost & SD \\
\hline $\begin{array}{l}\text { SK25 Sposoban } \\
\text { sam pouzdano } \\
\text { strukturirati } \\
\text { i organizirati } \\
\text { svakodnevni } \\
\text { život; uključujući } \\
\text { aktivnosti, zadatke, } \\
\text { sastanke i sl. }\end{array}$ & 4,02 &, 87 & 1 & 5 &,- 93 &, 21 & 1,59 & ,43 \\
\hline $\begin{array}{l}\text { OR17 Sposoban } \\
\text { sam za } \\
\text { razumijevanje } \\
\text { društvenih zbivanja } \\
\text { na nacionalnoj } \\
\text { i međunarodnoj } \\
\text { razini }\end{array}$ & 3,99 &, 81 & 2 & 5 &,- 26 &, 21 &,- 80 &, 43 \\
\hline $\begin{array}{l}\text { OR30_rec Ne } \\
\text { smatram da bi svijet } \\
\text { bolje funkcionirao } \\
\text { kad ne bi postojalo } \\
\text { toliko različitih } \\
\text { kultura }\end{array}$ & 3,98 & 1,22 & 1 & 5 & $-1,08$ &, 21 & ,26 & ,43 \\
\hline $\begin{array}{l}\text { SK7 Uživam radeći } \\
\text { u timu }\end{array}$ & 3,91 & 1,12 & 1 & 5 &,- 89 &, 21 & ,19 & ,43 \\
\hline $\begin{array}{l}\text { SK33 Mogu } \\
\text { podučavati učenike } \\
\text { o latentnim } \\
\text { zahtjevima društva } \\
\text { s ciljem postizanja } \\
\text { individualnog } \\
\text { osjećaja } \\
\text { odgovornosti }\end{array}$ & 3,89 &, 81 & 2 & 5 &, 02 &, 21 & $-1,08$ &, 43 \\
\hline $\begin{array}{l}\text { OR24 Imam } \\
\text { povjerenja u svoju } \\
\text { sposobnost da } \\
\text { djelujem i utječem } \\
\text { na rezultate } \\
\text { aktivnosti pri } \\
\text { postizanju cilja. }\end{array}$ & 3,87 &, 79 & 2 & 5 &,- 34 &, 21 &,- 23 & ,43 \\
\hline $\begin{array}{l}\text { SK20 Mnogi } \\
\text { ljudi kažu da sam } \\
\text { organizirana osoba }\end{array}$ & 3,85 & 1,08 & 1 & 5 &,- 84 &, 21 & ,13 &, 43 \\
\hline
\end{tabular}


Tablica 3. (nastavak) Deskriptivna statistika

\begin{tabular}{lllllllll}
\hline \multirow{2}{*}{ Čestica } & AS & SD & \multicolumn{2}{c}{ RANG } & \multicolumn{2}{c}{ ASIMETRIJA } & \multicolumn{2}{c}{ KURTOZA } \\
\cline { 3 - 7 } & $\min$ & $\max$ & vrijednost & SD & vrijednost & SD
\end{tabular}

SK6 Dobro predviđam kako će se drugi ponašati u određenim

$\begin{array}{llllllll}3,78 & , 57 & 3 & 5 & , 00 & , 22 & -, 29 & , 43\end{array}$
situacijama.

OR32 Mogu predvidjeti dugoročni utjecaj ljudskih akcija u $3,71 \quad, 80 \quad 2$ ,38 , $21 \quad-, 99$ , 43 budućnosti.

SK22 Kad god odlučim postići nešto, uspijem

$\begin{array}{llllllll}3,68 & , 86 & 1 & 5 & -, 68 & , 21 & , 56\end{array}$
ostvariti svoj cilj

SK16 Sposoban sam nastupati kao otvorena, spontana, duhovita i domišljata osoba pred grupom ljudi

$\begin{array}{llllllll}3,54 & 1,11 & 1 & 5 & -, 71 & , 21 & -, 05 & , 43\end{array}$
bez da zanemarim svoje mišljenje o temi

OR10 Rado sudjelujem u različitim društvenim $\mathrm{i}$ $\begin{array}{llll}3,33 & 1,04 & 1 & 5\end{array}$ , $21 \quad-, 67$ , 43 građanskim akcijama

SK15 Tijekom diskusije suprotnu stranu mogu uvjerit $\begin{array}{llllllll}3,27 & , 83 & 1 & 5 & -, 37 & , 21 & , 53 & , 43\end{array}$ u vlastito mišljenje

SK23 Sposoban sam raditi koncentrirano i bez prekida, noseći se $\mathrm{s}$ različitim zadatcima $\begin{array}{llllllll}3,15 & 1,08 & 1 & 5 & , 08 & , 21 & -, 88 & , 43\end{array}$ bez da osjećam pritisak 
Antonia Ćurić: Samoprocjena socijalnih kompetencija studenata ...

Tablica 3. (nastavak) Deskriptivna statistika

\begin{tabular}{|c|c|c|c|c|c|c|c|c|}
\hline \multirow{2}{*}{ Čestica } & \multirow{2}{*}{$\mathbf{A S}$} & \multirow{2}{*}{ SD } & \multicolumn{2}{|c|}{ RANG } & \multicolumn{2}{|c|}{ ASIMETRIJA } & \multicolumn{2}{|c|}{ KURTOZA } \\
\hline & & & $\min$ & $\max$ & vrijednost & SD & vrijednost & SD \\
\hline $\begin{array}{l}\text { SK14 Volim biti u } \\
\text { centru pozornosti }\end{array}$ & 2,35 & 1,09 & 1 & 5 & ,47 & ,21 &,- 28 & ,43 \\
\hline $\begin{array}{l}\text { SK21_rec Ne } \\
\text { osjećam da sam pod } \\
\text { stresom kad znam } \\
\text { da imam nekoliko } \\
\text { stvari za obaviti } \\
\text { tijekom dana }\end{array}$ & 2,30 & 1,14 & 1 & 5 &, 72 & ,21 &,- 09 & ,43 \\
\hline
\end{tabular}

Studenti su na gotovo svim varijablama iskazali slaganje u većoj mjeri i u potpunosti. Najvišu aritmetičku sredinu imala je varijabla „SK34 Učitelj bi trebao obraćati pažnju na oblikovanje socijalnih vještina učenika" na kojoj je većina studenata procijenila svoje slaganje u potpunosti $(\mathrm{AS}=4.91, \mathrm{SD}=0.31)$. Takav je rezultat ukazao da budući učitelji prepoznaju važnost socijalne kompletnosti učenika za budući život. Također, rezultat je u skladu s istraživanjima drugih autora (Buljubašić Kuzmanović, 2010; Kostović Vranješ i Ljubetić, 2008; Zrilić, 2010; Zwaans i sur., 2006) koji navode da svi učitelji, bez obzira na školski kontekst, promiču socijalni razvoj svojih učenika kao odgojno obrazovni cilj.

Studenti su procijenili osrednje slaganje na varijablama „SK23 Sposoban sam raditi koncentrirano $i$ bez prekida, noseći se s različitim zadatcima bez da osjećam pritisak" (AS=3.15, SD 1.08) i „SK15 Tijekom diskusije suprotnu stranu mogu uvjeriti u vlastito mišljenje“" (AS=3.27, SD 0.83). Nešto niži rezultat na prvoj varijabli je bio očekivan jer se građanstvo Republike Hrvatske suočavalo s velikim izazovima uzrokovanima epidemiološkom situacijom, prelaskom na online oblik rada te potresima, poplavama i drugim prirodnim katastrofama. Navedena pretpostavka je temeljena i povezana s rezultatima recentnih istraživanja (Li i sur., 2021; Obradović i Dmitrović, 2021.; Pandey i sur. 2020) u kojima se utvrdilo da se u posljednjoj godini povećao broj studenata koji se bore sa stresom i emocionalnim teškoćama.

Niži rezultat na varijabli „SK15 Tijekom diskusije suprotnu stranu mogu uvjeriti $u$ vlastito mišljenje" objašnjen je mogućim studentskim nerazumijevanjem razlike između pojmova „diskusija“ i ,svađa“. Naime, pojmovi diskusija i svađa često se koriste kao sinonimi, iako to u svojoj suštini nisu. Dok pojam svađa ima negativan prizvuk i označava raspravu bez poštivanja sugovornika, diskusija je rasprava u kojoj se objašnjavaju vlastiti stavovi pri čemu se poštuje mišljenje sugovornika (Jurčić, 2010). Diskusija je komunikacijska vještina koja se kao nastavna metoda provodi već u nižoj školskoj dobi, radi je čega važno njezino usvajanje. Niži rezultati na varijabli SK15 upućuju na potrebu veće 
implementacije diskusije u nastavne procese, kako bi se pojedinac osposobio za argumentirano zastupanje vlastitog mišljenja.

Najnižu aritmetičku sredinu imaju varijable ,SK21_rec Ne osjećam da sam pod stresom kad znam da imam nekoliko stvari za obaviti tijekom dana" $(\mathrm{AS}=2.30, \mathrm{SD}=1.14)$ i,$S K 14$ Volim biti u centru pozornosti“ $(\mathrm{AS}=2.35$, $\mathrm{SD}=1.10$ ). Objašnjenje takvih rezultata ponovno su objašnjeni vanjskim faktorima koji utječu na svakodnevni život. U budućim istraživanjima svakako bi trebalo pokušati izbjeći negativan prizvuk koji se javlja u varijabli „Volim biti u centru pozornosti“ $i$ usporediti dobivene rezultate.

Kako bi se utvrdilo razlikuje li se procjena kompetentnosti na faktorima Usmjerenost na cilj, Samoizražavanje i Globalne kompetencije spram godine studija koju ispitanici pohađaju provedena je neparametrijska zamjena za jednosmjernu ANOVA-u s nezavisnim skupinama: Kruskal-Wallis test. Utvrđeno je da ne postoji statistički značajna razlika na faktoru Usmjerenost na cilj $\left(\chi^{2}(4\right.$, $\mathrm{N}=127)=1,805, \mathrm{p}>0,05)$, na faktoru Samoizražavanje $\left(\chi^{2}(4, \mathrm{~N}=127)=1,136\right.$, $\mathrm{p}>0,05)$, ni na faktoru Globalne kompetencije $\left(\chi^{2}(4, \mathrm{~N}=127)=4,360, \mathrm{p}>0,05\right)$, spram godine studija na kojoj su bili ispitanici, odnosno da su se ispitanici osjećali jednako kompetentni bez obzira na godinu studija. Možemo pretpostaviti da studenti procjenjivane socijalne kompetencije ne prepoznaju u studijskom kurikulumu te ih smatraju razvojnim sposobnostima koje stječu kroz svakodnevni život, radi čega godina studija nije značajnije doprinijela razlici u procjeni vlastitih kompetencija. Dobiveni rezultati su različiti u odnosu na samoprocjenu kompetencija održivog razvoja i samoprocjenu vrijednosti održivog razvoja koje su ispitane ranijim istraživanjima (Anđić i Ćurić, 2020; Anđić, 2015; Cvitković, 2018; Vukelić i sur., 2018). Istraživanja su, naime, pokazala da tijekom završavanja obveznog obrazovanja za učitelje studenti procjenjuju povećanje socijalne osjetljivosti, vještina nenasilne komunikacija, interakcija, i sl., što je suprotno rezultatima dobivenim rezultatima.

Poznavanje stranih jezika ispitivalo se otvorenim pitanjem u kojem su studenti upisivali kojim se sve stranim jezicima koriste. Utvrđeno je da se svi studenti (100\%) koriste engleskim jezikom, dok je manji broj studenata koji govore talijanski (26,8\%), njemački (24,4 \%), francuski (3,9\%), slovenski $(2,4 \%)$ i španjolski jezik $(2,4 \%)$, a tek su pojedini studenti naznačili poznavanje jezika poput ukrajinskog $(0,8 \%)$ i češkog jezika $(0,8 \%)$.

Gledajući poznavanje stranih jezika po ispitaniku utvrđeno je da 53,5\% ispitanika poznaje jedan strani jezik, 32,3\% dva strana jezika, 13,4 \% govori tri strana jezika te $0,8 \%$ poznaje četiri strana jezika.

Autori Villegas i Lucas (2002) dokazali su da učenici više uče od učitelja koji podučavaju u kulturno i jezično raznolikim učionicama, nego od onih koji imaju didaktičniji pristup (Keengwe, 2016). Imajući to na umu, zanimalo nas je postoji li statistički značajna razlika u procjeni socijalnih kompetencija između studenata koji govore više stranih jezika. Kako bi se utvrdilo razlikuje li se 
procjena kompetentnosti na faktorima Usmjerenost na cilj, Samoizražavanje i Globalne kompetencije spram broja jezika koji ispitanik govori još je jednom provedena neparametrijska zamjena za jednosmjernu ANOVA-u s nezavisnim skupinama: Kruskal-Wallis test (Tablica 4).

Tablica 4. Procjena kompetentnosti na faktorima Usmjerenost na cilj, Samoizražavanje i Globalne kompetencije spram broja stranih jezika koji ispitanik govori

\begin{tabular}{lccccccccc}
\hline Nazivi faktora & $\begin{array}{c}\text { br. } \\
\text { stranih } \\
\text { jezika }\end{array}$ & $\mathbf{N}$ & $\mathbf{C}$ & $\mathbf{Q}_{3-1}$ & $\begin{array}{c}\text { AS } \\
\text { rang }\end{array}$ & Min & Max & $\chi^{\mathbf{2}(d f)}$ & $\mathbf{p}$ \\
& 1 & 68 & 3,78 & 0,71 & 58,43 & 2,43 & 4,71 & & \\
$\begin{array}{l}\text { Usmjerenost na } \\
\text { cilj }\end{array}$ & 2 & 41 & 4,00 & 0,57 & 66,28 & 3,29 & 4,71 & 9,637 & 0,022 \\
& 3 & 17 & 4,29 & 0,71 & 84,29 & 3,43 & 4,57 & $(3)$ & \\
& 4 & 1 & & & 4,00 & & & & \\
& 1 & 68 & 3,60 & 0,50 & 52,29 & 2,60 & 4,60 & & \\
Samoizražavanje & 2 & 41 & 3,90 & 0,65 & 75,55 & 3,10 & 5,00 & 15,394 & 0,002 \\
& 3 & 17 & 4,2 & 0,55 & 82,65 & 3,10 & 4,80 & $(3)$ & \\
& 4 & 1 & & & 70,00 & & & & \\
\hline & 1 & 68 & 3,89 & 0,67 & 59,93 & 2,89 & 4,89 & & \\
Globalne & 2 & 41 & 4,00 & 0,39 & 69,04 & 3,11 & 4,78 & 3,070 & 0,381 \\
kompetencije & 3 & 17 & 4,00 & 0,56 & 70,24 & 3,56 & 4,67 & $(3)$ & \\
& 4 & 1 & & & 28,00 & & & & \\
\hline
\end{tabular}

Realizacijom Kruskal-Wallisova testa utvrđeno je da ne postoji statistički značajna razlika na faktoru Globalne kompetencije spram poznavanja stranih jezika $\left(\chi^{2}(3, N=127)=15,394, p>0,05\right)$. Kod preostala dva faktora pronađena je statistički značajna razlika spram poznavanja stranih jezika te je ona opisana u nastavku.

Utvrđeno je da postoji statistički značajna razlika na faktoru Usmjerenost na cilj spram poznavanja stranih jezika $\left(\chi^{2}(3, \mathrm{~N}=127)=9,637, \mathrm{p}<0,05\right)$. Pri tome broj jezika kojim ispitanici govore odražava srednji udio varijance $(\mathrm{y} 2=$ 0,0765) na rezultatu faktora Usmjerenosti na cilj, što ukazuje na značajnu povezanost između varijabli.

Višestruke usporedbe provedene su Mann-Whitney U testom uz Bonferoni korekciju za kontrolu alpha pogreške. Pronađeno je da postoji statistički značajna razlika između ispitanika koji govore jedan strani jezik u odnosu na one koji govore tri strana jezika ( $U=359,00, z=-2,42, p<0,05)$, pri čemu su ispitanici koji govore jedan strani jezik $\left(C_{1}=3,79, Q_{3-1}=0,71\right)$ manje procijenili faktor 
usmjerenosti na cilj nego ispitanici koji govor tri strana jezika $\left(\mathrm{C}_{3}=4,29, \mathrm{Q}_{3}\right.$ $=0,71)$. Ustanovljena je mala veličina efekta jezika $r=-0,21$.

Također, statistički značajna razlika utvrđena je i između ispitanika koji govore dva strana jezik u odnosu na one koji govore tri strana jezika $(U=231,00$, $\mathrm{z}=-2,02, \mathrm{p}<0,05)$. Ispitanici koji govore dva strana jezika $\left(\mathrm{C}_{2}=4,00, \mathrm{Q}_{3-1}=0,57\right)$ manje procjenjuju faktor usmjerenosti na cilj nego ispitanici koji govor tri strana jezika $\left(C_{3}=4,29, Q_{3-1}=0,71\right)$. Primijećena je mala veličina efekta jezika $r=-$ 0,18 . Što se tiče ostalih grupa, nije utvrđena statistički značajna razlika.

Analiza na faktoru Samoizražavanje pokazala je da postoji statistički značajna razlika spram poznavanja stranih jezika $\left(\chi^{2}(3, N=127)=15,394, p<0,05\right)$. Broj jezika kojim ispitanici govore ukazuje na značajnu povezanost između varijabli, odnosno, odražava srednji udio varijance $(\mathrm{y} 2=0,1222)$ na rezultatu faktora Samoizražavanje.

Ponovno su provedene višestruke usporedbe Mann-Whitney U testom uz Bonferoni korekciju za kontrolu alpha pogreške kojima je ustanovljeno da postoji statistički značajna razlika između ispitanika koji govore jedan strani jezik u odnosu na one koji govore dva strana jezika ( $U=882,50, z=-3,209$ $\mathrm{p}<0,05)$. Ispitanici koji govore jedan strani jezik $\left(\mathrm{C}_{1}=3,60, \mathrm{Q}_{3-1}=0,50\right)$ su manje procijenili faktor samoizražavanje nego ispitanici koji govore dva strana jezika $\left(\mathrm{C}_{2}=3,90, \mathrm{Q}_{3-1}=0,65\right)$. Na faktoru Samoizražavanje je primijećena mala veličina efekta broja jezika koji ispitanici govore $\mathrm{r}=-0,27$.

Usto, zamijećena je statistički značajna razlika između ispitanika koji govore jedan strani jezik u odnosu na one koji govore tri strana jezika $(U=305,50$, $\mathrm{z}=-3,00, \mathrm{p}<0,05)$. Pritom su ispitanici koji govore jedan strani jezik $\left(\mathrm{C}_{1}=3,60\right.$, $\left.\mathrm{Q}_{3-1}=0,50\right)$ manje procijenili faktor Samoizražavanja nego ispitanici koji govor tri strana jezika $\left(\mathrm{C}_{3}=4,2, \mathrm{Q}_{3-1}=0,55\right)$ čime se ustvrdila se mala veličina efekta jezika $\mathrm{r}=-0,28$.

Konačno, između preostalih grupa nije pronađena statistički značajna razlika.

Rezultati sugeriraju razliku u procjeni kompetencija na faktorima socijalnih kompetencija Samoizražavanje i Usmjerenost na cilj kod studenata koji govore više od jednog stranog jezika, odnosno višejezičnim studentima nasuprot studentima koji govore samo jedan strani jezik. Faktori Samoizražavanje i Usmjerenost na cilj dominantno opisuju organizacijske vještine, inovativnost, volju za sudjelovanjem i ekstrovertiranost, a relevantna istraživanja upravo podupiru dobrobit višejezičnosti u pogledu pozornosti (Bak i sur. 2016 prema Mehmedbegović-Smith, 2020), uvažavanja drugih i samoizražavanja (Račić, 2013). Radi navedenog možemo zaključiti da višejezičnost u tom smislu, treba biti jedan od odgojno obrazovnih ciljeva kojim će se pojedinac afirmirati profesionalno i osobno (Račić, 2013).

Kako bi se ispitala treća hipoteza, odnosno razlika između samoprocjene kompetencija studenata s obzirom na veličinu mjesta iz kojeg student dolazi 
formulirano je pitanje otvorenog tipa u kojem su studenti samostalno upisivali naziv mjesta. Svakom mjestu su naknadno dodijeljene oznake velikog, srednjeg ili malog mjesta, prema podatcima iz popisa stanovništva 2011. godine. Oznakom „veliko mjesto“ označeni su gradovi od 45000 stanovnika na više, srednje mjesto gradovi od 20000 do 45000 stanovnika, a malo mjesto svi gradovi koji imaju manje od 20000 stanovnika. Utvrđeno je da $52 \%$ ispitanika dolazi iz velikog mjesta, $4 \%$ iz srednjeg mjesta i $44 \%$ iz malog mjesta. Iznova je izvršena neparametrijska zamjena za jednosmjernu ANOVA-u s nezavisnim skupinama: Kruskal-Wallis test te je ustanovljeno da ne postoji statistički značajna razlika na faktoru Usmjerenost na cilj $\left(\chi^{2}(2, \mathrm{~N}=127)=0,119, \mathrm{p}>0,05\right)$, Samoizražavanje $\left(\chi^{2}(2, \mathrm{~N}=127)=0,823, \mathrm{p}>0,05\right)$ ni na faktoru Globalne kompetencije $\left(\chi^{2}(2, \mathrm{~N}=127)=0,209, \mathrm{p}>0,05\right)$ spram veličine mjesta iz koje ispitanici dolaze $(\mathrm{p}>0,05)$.

Razlika između samoprocjene kompetencija s obzirom na veličinu mjesta ispitivana je s pretpostavkom da veći gradovi nude više mogućnosti za razvoj različitih interkulturalnih i građanskih kompetencija te da će se ispitanici većih mjesta procjenjivati kompetentnijima $u$ odnosu na ispitanike manjih mjesta. Međutim, premda su rezultati pokazali ne postojanje razlike, treba ih uzeti s oprezom, jer su dobiveni na malenom uzorku koji nije ujednačen.

\section{ZAKLJUČAK}

Rezultati istraživanja ukazali su na primjenjivost konstruiranih skala, ali kako je riječ o preliminarnom istraživanju provedenom na malenom uzorku ove zaključke treba iznijeti s iznimnim oprezom. Preporuka je za buduća istraživanja povećati uzorak kako bi bio reprezentativniji i kako bi rezultati bili značajniji. Također, potrebna je daljnja nadogradnja samog mjernog instrumenta. Ovako postavljen upitnik može biti osnova za daljnji razvoj istraživanja socijalnih kompetencija učitelja, stoga možemo zaključiti da je prva hipoteza djelomično potvrđena.

Drugi istraživački zadatak bio je utvrditi stavove studenata o vlastitim socijalnim kompetencijama. Dobiveni su visoki rezultati aritmetičkih sredina o procjeni vlastitih socijalnih kompetencija na faktoru Usmjerenost na cilj $(\mathrm{M}=3,86, \mathrm{SD}=0,473)$, faktoru Samoizražavanje $(\mathrm{M}=3,74, \mathrm{SD}=0,466)$ i na faktoru Globalne kompetencije $(\mathrm{M}=3,96, \mathrm{SD}=0,373)$ čime je druga hipoteza potvrđena.

Treća i peta hipoteza su potvrđene, jer je istraživanje pokazalo da godina studija ispitanika i veličina prebivališta nisu povezane s većom procjenom socijalne kompetentnosti studenata.

Četvrta hipoteza je djelomično potvrđena - Studenti koji govore veći broj stranih jezika procjenjuju se kompetentnijima u odnosu na studente koji govore manji broj stranih jezika. Naime, istraživanje je pokazalo da postoji povezanost 
između studenata koji govore tri strana jezika i Usmjerenosti na cilj, u odnosu na studente koji govore jedan i dva strana jezika, pri čemu se studenti koji govore tri strana jezika procjenjuju više faktor usmjerenosti na cilj. Također, studenti koji govore dva i tri strana jezika procjenjuju višim faktor Samoizražavanja od studenata koji govore jedan strani jezik. S obzirom na to da održivi razvoj ima i lokalnu i globalnu komponentu, njihova mogućnost informiranja, razumijevanja i pristupu informacija vezanih za globalna događanja, međuodnose i trendove je veća. Moguće je da se ispitanici s manjim poznavanjem stranih jezika osjećaju ograničenije i lokaliziranije te zbog komponente poznavanja globalnih međuodnosa, izuzev onih interpretiranih kroz njima poznate jezike, smatraju da imaju manje kompetencije u odnosu na poznavatelje više stranih jezika. Time se otvara prostor za daljnja istraživanja zbog moguće povezanost socijalnih kompetencija iz konteksta održivog razvoja i jezične kompetentnosti, te naglašava važnost višejezičnosti u kontekstu vlastitog razvoja i cjeloživotnog učenja.

Konačno, socijalna kompetencija nije nešto novo, ona proizlazi iz metakognicije odnosno poznavanja i mogućnosti promatranja procesa unutar sebe i svojih reakcija, a na tome su se temeljili još i drevni sistemi obrazovanja u starim kulturama Grčke, Rima, Kine, Indije i dr. koji su proizlazili od religije i poznavanja sebe. Bez mogućnosti promatranja procesa unutar sebe svaki daljnji razvoj i reakcija prema drugim ljudima je nemoguća. Potrebno je prepoznati utjecaj odgojno obrazovnog programa i potpomognuti daljnju mogućnost osnaživanja budućih učitelja u tom polju, poglavito u njihovoj praktičnoj primjeni, jer održiva budućnost nije moguća bez obrazovanja socijalno kompetentnih učitelja koji obrazuju buduće građane.

\section{NAPOMENA}

Ovaj je rad nastao u sklopu znanstvenog projekta „Povezanost s prirodom, organizacija slobodnog vremena djece školske dobi i digitalne tehnologije“ (voditeljica: izv. prof. dr. sc. Dunja Anđić) koji se uz potporu Sveučilišta u Rijeci izvodi na Učiteljskom fakultetu u Rijeci (http://www.ufri.uniri.hr/files/ znanstveni\%20projekti/dunja_andjic_projekt.pdf).

\section{LITERATURA}

Anđić, D. (2015). Doprinosi razvoju kompetencija učitelja osnovnih škola u odgoju i obrazovanju za održivi razvoj. Napredak : Časopis za pedagogijsku teoriju i praksu, 156(4), 367-383. https://bib.irb.hr/prikazi-rad?\&rad=801341

Anđić, D. (2017). Contribution to the Development of Kindergarten / Preschool Teachers ' Competences for Education for Sustainable Development in Preschool Institutions. Hrvatski časopis za odgoj i obrazovanje, 19(3), 213-232. https://doi. org/10.15516/cje.v19i0.2712 
Anđić, D. i Ćurić, A. (2020). What are the attitudes of future teachers about sustainable development in Croatia? Validation and adaptation of the attitudes toward sustainable development scale. Proceedings of ICERI2020 Conference (str. 1448-1457). IATED. https://doi:10.21125/iceri.2020.0374

Anđić, D. i Tatalović Vorkapić, S. (2015). Kako mjeriti održivo ponašanje? Adaptacija i validacija upitnika o održivom ponašanju. Revija Za Sociologiju, 45(1), 69-97. https://doi.org/10.5613/rzs.45.1.3

Anđić, D. i Tatalović Vorkapić, S. (2017). Teacher education for sustainability: the awareness and responsibility for sustainability problems. Journal of Teacher Education for Sustainability, 19(2). 121-137. https://doi:10.1515/jtes-2017-0018

Bogović, N. D. i Čegar, S. (2012). Education principles in a model of strong sustainability. Problems of Education in the 21st Century, 44, 10-19. http://www.scientiasocialis.lt $/ \mathrm{pec} / \mathrm{node} / 729$

Borić, E, Jindra, R. i Škugor, A. (2008). Razumijevanje i primjena sadržaja cjeloživotnog učenja za održivi razvoj. Odgojne znanosti, 2(16); 315-327. https://hrcak.srce. $\mathrm{hr} / 29572$

Buljubašić-Kuzmanović, V. (2010). Socijalne kompetencije i vršnjački odnosi u školi. Pedagogijska Istraživanja, 7(2), 191-201. https://hrcak.srce.hr/118097

Cvitković, E. (2018). Održivo ponašanje budućih učitelja [diplomski rad, Sveučilište u Rijeci]. Repozitorij Filozofskog fakulteta Sveučilišta u Rijeci. https:/urn.nsk.hr/ urn:nbn:hr:186:514859

Dodge, K., Pettit, G., McClaskey, C., Brown, M. i Gottman, J. (1986). Social Competence in Children. Monographs of the Society for Research in Child Development, 51(2), I-85. https://doi:10.2307/1165906

Jurčić, M. (2010). Nastavni kurikulum kao poticaj razvoju socijalnih kompetencija učenika. Pedagogijska Istraživanja, 7(2), 205-217. https://hrcak.srce.hr/118090

Kanning, U. P. i Herrmann, C. (2012). Measuring social competencies in the teaching profession - development of a self-assessment procedure. Journal Für Bildungsforschung Online, 4(1), 140-154. https://doi: 10.25656/01:7055

Keengwe, J. (2016). Handbook of Research on Promoting Cross-Cultural Competence and Social Justice in Teacher Education. IGI Global Online Bookstore. https://doi. org/10.4018/978-1-5225-0897-7

Knippenberg, L., Edelmann, E. i Hermans, F. (2005). Shaping the social dimension of sustainable development. U S. van den Burg, G. Spaargaren, H. Waaijers (ur.), Wetenschap met beleid, beleid met wetenschap (str. 64-68). Wageningen, the Netherlands: Wageningen Universiteit. https://www.researchgate.net/profile/ Frans-Hermans-3/publication/254871461_Shaping_the_social_dimension_of sustainable_development/links/548562030cf283750c37138c/Shaping-the-socialdimension-of-sustainable-development.pdf

Kostović-Vranješ, V. (2016). Inicijalno obrazovanje i profesionalno usavršavanje učitelja usmjereno prema osposobljavanju za promicanje obrazovanja za održivi 
razvoj. U N. Mihaljević (ur.) Zbornik radova Filozofskog fakulteta u Splitu (str. 166-188). Filozofski fakultet u Splitu. https://hrcak.srce.hr/154589

Laininen, E. (2019). Transforming Our Worldview Towards a Sustainable Future. U J. W. Cook (ur.), Sustainability, Human Well-Being, and the Future of Education (str. 161-200). Springer International Publishing. https://doi. org/10.1007/978-3-319-78580-6_5

Lay, V. i Puđak, J. (2008). Sociološke dimenzije odgoja i obrazovanja za održivi razvoj. U V. Uzelac, L. Vujičić (ur.), Cjeloživotno učenje za održivi razvoj, 1. svezak (str. 95-105). Sveučilište u Rijeci, Učiteljski fakultet u Rijeci.

Leganés-Lavall, E. N. i Pérez-Aldeguer, S. (2016). Social competence in higher education questionnaire (CCSES): Revision and psychometric analysis. Frontiers in Psychology, 7(34), 1-6. https://doi.org/10.3389/fpsyg.2016.01484

Li, Y., Zhao, J., Ma, Z., McReynolds, L. S., Lin, D. i Chen, Z. (2021). Mental Health Among College Students During the COVID-19 Pandemic in China: A 2-Wave Longitudinal Survey. Journal of affective disorders, 281, 597-604. https://doi.org/10.1016/j.jad.2020.11.109

Livazović, G. (2012). Pedagoško utemeljenje kurikuluma socijalnih kompetencija u školi. Pedagogijska istraživanja, 9(1-2), 59-81. https://hrcak.srce.hr/113446

Martinsone, B. (2016). Social Emotional Learning: Implementation of SustainabilityOriented Program in Latvia. Journal of Teacher Education for Sustainability, 18(1), 57-68. https://doi: 10.1515/jtes-2016-0005

Mebratu, D. (1998). Sustainability and sustainable development: historical and conceptual review. Environmental impact assessment review, 18(6), 493-520. https:// doi.org/10.1016/S0195-9255(98)00019-5

Mehmedbegović-Smith, D. (2020). Zdrava lingvistička prehrana (HLD): učenje jezika kao ključan sastojak čovjekove dobrobiti. U A. Peko, M. Ivanuš Grmek i J. Delcheva Dizarevikj (ur.), (2020). Međunarodna znanstvena konferencija Didaktički izazovi III: didaktička retrospektiva i perspektiva Kamo i kako dalje? (str. 67 - 77). Sveučilište Josipa Jurja Strossmayera u Osijeku Fakultet za odgojne i obrazovne znanosti. https://drive.google.com/ file/d/1Q97LhzjTDDuu097QRmuzjhZnhlEoBXEX/view

Mubtaker, Y. (2020). SDGs for Everyone. Independently published.

Obradović, J. i Dmitrović, M. SWOT analiza on-line nastave u toku pandemije. U V. Katić (ur.), XXVII skup trendovi razvoja: "On-line nastava na univerzitetima", (str. 87 - 90). Fakultet tehničkih nauka Univerziteta u Novom Sadu. http://www. trend.uns.ac.rs/stskup/trend_2021/radovi/T1.1/T1.1-18.pdf

OECD (2018). Questions related to global competence in the student questionnaire. https://www.oecd.org/pisa/PISA-2018-Global-Competence-Questionnaire.pdf

Pandey, U., Corbett, G., Mohan, S., Reagu, S., Kumar, S., Farrell, T. i Lindow, S. (2021). Anxiety, depression and behavioural changes in junior doctors and medical students associated with the coronavirus pandemic: a cross-sectional survey. 
Antonia Ćurić: Samoprocjena socijalnih kompetencija studenata ...

The Journal of Obstetrics and Gynecology of India, 71(1), 33-37. https://doi: 10.1007/s13224-020-01366-w

Račić, M. (2013). Modeli kompetencija za društvo znanja. Suvremene Teme: Međunarodni Časopis Za Društvene i Humanističke Znanosti, 6(1), 86-100. https://hrcak.srce.hr/112805

Raditya-Ležaić, A., Boromisa, A. M. i Tišma, S. (2018). Comparative analysis of education for sustainable development and the need for experts in sustainable development in Croatia. Socijalna Ekologija, 27(2), 165-180. https://doi.org/10.17234/ SocEkol.27.2.3

Rončević, N., Ledić, J. i Ćulum, B. (2008). „Nisam sigurna što je, ali je bitno“ - analiza stavova studenata Sveučilišta u Rijeci o održivom razvoju. Suvremene Teme: Međunarodni Časopis Za Društvene i Humanističke Znanosti, 1(1), 62-75. https:// hrcak.srce.hr/35232

UN (1993). Agenda 21: Programme of Action for Sustainable Development; Rio Declaration on Environment and Development; Statement of Forest Principles: the Final Text of Agreements Negotiated by Governments at the United Nations Conference on Environment and Development (UNCED), 3-14 June 1992. United Nations Department of Information. https://digitallibrary.un.org/record/170126

UNESCO (2005). UN Decade of Education for Sustainable Development: Linkages Between the Global Initiatives in Education. Paris. UNESCO.

UNESCO (2015). Rethinking Education. Towards a global common good? Paris. UNESCO https://unesdoc.unesco.org/ark:/48223/pf0000232555

UNESCO (2017). Education for Sustainable Development: Learning Objectives. Paris. UNESCO https://unesdoc.unesco.org/ark:/48223/ pf0000247444?posInSet=1\&queryId=aa1670dc-4b43-4762-ac66-688bf3a9d37b

Villegas, A. M. i Lucas, T. (2002). Preparing culturally responsive teachers: Rethinking the curriculum. Journal of teacher education, 53(1), 20-32. https://doi: $10.1177 / 0022487102053001003$

Vukelić, N, Rončević, N. i Vinković, A. (2018). Jesu li budući nastavnici spremni za integraciju obrazovanja za održivi razvoj u nastavu? U E. Dedić Bukvić i S. BjelanGuska (ur.), Ka novim iskoracima u odgoju i obrazovanju. Zbornik radova sa 2. međunarodne znanstveno- stručne konferencije (str. 326-338). Filozofski fakultet u Sarajevu. https://www.researchgate.net/publication/337010122_Jesu_li_buduci_nastavnici_spremni_za_integraciju_OOR_u_nastavu

World commission on environment and development (1987). Our common future. United Nations. https://www.are.admin.ch/are/en/home/media/publications/sustainable-development/brundtland-report.html

Zrilić, S. (2010). Kvaliteta komunikacije i socijalni odnosi u razredu. Pedagogical Research, 7(2), 231-240. https://hrcak.srce.hr/118096

Zwaans, A., Ten Dam, G. i Volman, M. (2006). Teachers' goals regarding social competence. European Journal of Teacher Education, 29(2), 181-202. https://doi. org/10.1080/02619760600617375 